\title{
Technology-product integration in SMEs: the unclear separation between the technology and product development
}

\author{
Juliana Sayuri Kurumoto, Maicon Gouvea de Oliveira, Daniel Capaldo Amaral \\ University of São Paulo \\ e-mail: kurumoto@sc.usp.br
}

\begin{abstract}
The differences between technology and product are clear and established in the literature. This paper investigated the hypothesis that some SMEs are unable to distinguish technologies and products within their innovation processes, occasioning product technology integration problems. This study aims to explore the technology-product integration in SMEs through the analysis of the application of simultaneous and sequential integration strategies. A case research method was employed to investigate and compare successful product innovations of 22 SMEs. Data were collected through interviews and using a semi-structured questionnaire. The findings indicate that most of these companies either do not use integration strategies or use them inappropriately. The technology-product integration management in SMEs needs further investigation and new methods. This research is one of the first attempts to investigate the technology-product integration within SMEs, which is a class of companies essential for innovation in industry. Past studies have focused large companies only, which can be considered a complete different context.
\end{abstract}

Keywords: innovation management, technology-product integration, integration strategies, SMEs.

\section{Introduction}

Innovation is a source of competitive advantage, but is also a challenge to many organizations, since it embraces different processes, uncertainties and substantial investments. The innovation process comprises the development of technologies and products (LAKEMOND et al., 2007; OLIVEIRA et al., 2011). According to Clark and Wheelwright (1993), the management of innovation achieves better performance if technology and product development projects are planned jointly and conducted separately, which is known as technology-product integration through a sequential strategy. Other studies endorse this integration strategy and shows that it can allows for better communication, improves efficiency of resources, reduces risks and supports effective application of new technologies (ELDRED; McGRATH, 1997a; DREJER, 2002; NOBELIUS, 2004).

Technology-product integration has been already investigated since the 90's and knowledge has been provided to support companies. Nobelius (2004) stated the importance of recognizing time and resources which are spent on the integration, which, if underestimated, can lead to introduction of immature technologies and to low quality products. In addition, Eldred and McGrath (1997b) showed that the ineffective integration results in problems of costs and time to market. Therefore, technology-product integration is acknowledged to be imperative to achieve successful innovations (STOCK; TATIKONDA, 2004; DREJER, 2002; SCHULZ et al., 2000).
Recent progress within this context was made through the adoption of technology management frameworks and readiness levels. Technology management frameworks, such as: Eldred and McGrath (1997a), Ajamian and Koen (2002), Phaal, Farrukh and Probert (2004) and Cooper (2006); describes processes and tools used for technology development. Technology readiness levels (TRLs) can be considered part of these frameworks. They have been highlighted, since their development by NASA (MANKINS, 1995), as an outstanding method whose proposal can enhance technology management and technology-product integration (CLAUSING; HOLMES, 2010).

Most of the studies regarding technology-product integration have dealt with large companies, in spite of small and medium enterprises (SMEs) are a key source of product innovations (ROPER, 1997; STAM; WENNBERG, 2009). A search conducted in the Web of Science and Scopus databases confirmed the scarcity of information about the integration in SMEs. Studies regarding technology transfer in universities and industrial networks were the only ones which presented some contribution in this sense. Then, the investigation of technology-product integration in SMEs can be stated as a research opportunity.

This paper aims to investigate the application of strategies of technology-product integration in SMEs. This topic, which can involve sequential and simultaneous strategies, is related to the time dimension of technology and product 
projects as well as to the approach followed to manage the introduction of new technologies into new products. To this end, a case research method was employed to explore 22 successful product innovations selected in SMEs from a Brazilian technological pole. Data were collected through interviewees and a semi-structured questionnaire, whose key questions are described in the appendix of this paper (Appendix 1), and then analysed qualitatively through individual and longitudinal approaches. Some questions to be answered through these cases are: Do SMEs manage separately product and technology projects as suggested by the theory? If yes, which integration strategy do they apply: simultaneous or sequential? What lead them to adopt a strategy?

Next sections of this paper describe the literature review, the research method and the qualitative analysis of data collected. At the end, results are discussed with regard to theoretical and empirical contributions to technology-product integration in SMEs.

\section{Literature review}

\subsection{Technology-product integration}

Iansiti (1998) and Eldred and McGrath (1997a) defined technology-product integration as the application of technologies, which were already developed, to one or more products that are being developed. Additionally, Drejer (2002) declared that the integration will only exist if technology and product development decisions are interrelated and compatible. Stock and Tatikonda (2004) addressed the integration from the perspective of external agents and explain edit as a process to support the acquisition and incorporation of technologies supplied by external sources.

In regard to the approach that can be adopted to analyse the integration, Iansiti (1998) followed one based on the standpoint of organizational areas, which addresses integration between research and development (R\&D) and engineering areas within large companies. On the other hand, recent studies considered the standpoint of business processes. For example, Cooper (2008) and Barczak, Griffin and Kahn (2009), which dealt with the product development process, and Creveling, Slutsky and Antis (2003) and Cooper (2006), which focused on the technology development process.

Iansiti (1998) argued that the technology-product integration is as result of cycles of knowledge generation, retention and application. Furthermore, Drejer (2002) stated that the integration is comprised of three dimensions: activity, time and aspects. Following this approach, a compilation of dimensions which were cited in key studies was made. This compilation is described in Table 1.
Table 1. Dimensions of technology-product integration.

\begin{tabular}{|c|c|c|}
\hline Author & Dimension & Characteristics \\
\hline \multirow{3}{*}{$\begin{array}{l}\text { Eldred } \\
\text { and } \\
\text { McGrath } \\
\text { (1997b) }\end{array}$} & Synchronization & $\begin{array}{l}\text { Technology readiness and } \\
\text { product concept approval }\end{array}$ \\
\hline & $\begin{array}{l}\text { Technology } \\
\text { Equalization }\end{array}$ & $\begin{array}{l}\text { Assessment of technologies } \\
\text { required for product } \\
\text { development }\end{array}$ \\
\hline & $\begin{array}{l}\text { Technology } \\
\text { Transfer }\end{array}$ & $\begin{array}{l}\text { Development of a transition plan } \\
\text { by transition teams }\end{array}$ \\
\hline \multirow{2}{*}{$\begin{array}{l}\text { Iansiti } \\
(1998)\end{array}$} & $\begin{array}{l}\text { Domain-Specific } \\
\text { Knowledge }\end{array}$ & Explicit knowledge \\
\hline & $\begin{array}{c}\text { Context-Specific } \\
\text { Knowledge }\end{array}$ & Tacit knowledge \\
\hline \multirow{3}{*}{$\begin{array}{l}\text { Drejer } \\
(2002)\end{array}$} & Aspects & $\begin{array}{l}\text { Organizational areas that make } \\
\text { up a company }\end{array}$ \\
\hline & Activities & $\begin{array}{l}\text { Essential tasks of each } \\
\text { department }\end{array}$ \\
\hline & Time Horizon & $\begin{array}{l}\text { Well-timed technology and } \\
\text { product availability }\end{array}$ \\
\hline \multirow{3}{*}{$\begin{array}{l}\text { Nobelius } \\
\text { (2004) }\end{array}$} & Synchronization & $\begin{array}{l}\text { Technology and product } \\
\text { strategies and technology } \\
\text { readiness }\end{array}$ \\
\hline & Scope Transfer & Knowledge transfer \\
\hline & $\begin{array}{c}\text { Transfer } \\
\text { Management }\end{array}$ & $\begin{array}{l}\text { Transfer of resources (human, } \\
\text { organizational, and/or } \\
\text { procedures) }\end{array}$ \\
\hline \multirow{2}{*}{$\begin{array}{l}\text { Stock and } \\
\text { Tatikonda } \\
(2004)\end{array}$} & $\begin{array}{l}\text { Technology } \\
\text { uncertainty }\end{array}$ & $\begin{array}{l}\text { Novelty, complexity and } \\
\text { tacitness }\end{array}$ \\
\hline & $\begin{array}{l}\text { Interorganizational } \\
\text { interaction } \\
\end{array}$ & $\begin{array}{l}\text { Communication, coordination } \\
\text { and cooperation }\end{array}$ \\
\hline
\end{tabular}

Dimensions that are presented in Table 1 can be summarized in three questions, as proposed by Johansson et al. (2006): What will be transferred? When will it be transferred? How will it be transferred? The first question has to do with the following dimensions: technology equalization, knowledge, aspects and scope transfer. The second question considers the synchronization and time dimensions. And the third question involves: technology transfer, activities and transfer management.

\subsection{SMEs, large companies and technology-product integration}

According to the European Commission (2005), small and medium enterprises (SMEs) embrace companies with less than 250 employees and with annual revenue lower than 50 million of euros. Moreover, SMEs differ from large companies, not only regarding size and revenue, as presented in Table 2, but also regarding the innovation process (BOS-BROUWERS, 2010). As a result, practices used for managing innovation in SMEs need customization to fulfil the requirements of this class of company. 
Table 2. Differences between SMEs and large companies (Adapted from BOS-BROUWERS, 2010).

\begin{tabular}{|c|c|}
\hline SME & Large company \\
\hline $\begin{array}{l}\text { Dominant role of the } \\
\text { entrepreneur/owner }\end{array}$ & $\begin{array}{c}\text { Management is delegated } \\
\text { through board of directors and } \\
\text { shareholders }\end{array}$ \\
\hline $\begin{array}{l}\text { Lack of resources (capital, } \\
\text { time, knowledge and skilled } \\
\text { personnel) }\end{array}$ & $\begin{array}{c}\text { Economy of scale, abundance } \\
\text { of resources }\end{array}$ \\
\hline Flexible organization & $\begin{array}{c}\text { Bureaucratic and rigid } \\
\text { organization }\end{array}$ \\
\hline Focus on short term goals & $\begin{array}{l}\text { Focus on mid to long term } \\
\text { goals }\end{array}$ \\
\hline $\begin{array}{l}\text { Stronger local/regional focus } \\
\text { and customer needs orientation }\end{array}$ & $\begin{array}{l}\text { Stronger (inter)national focus } \\
\text { and looser ties with customers }\end{array}$ \\
\hline Low degree of formalization & High degree of formalization \\
\hline
\end{tabular}

Technology-product integration is one of the management practices capable of enhancing innovation management in SMEs. However, most of the previous studies addressed the integration within large companies (IANSITI, 1998; NOBELIUS, 2004; MAGNUSSON; JOHANSSON, 2008; KARLSSON; TAYLOR; TAYLOR, 2010; JUGEND; SILVA, 2012). Additionally, a search conducted in the Web of Science and Scopus databases testified to the lack of information about the integration in SMEs. Studies considering technology transfer in universities and industrial networks were the only ones which presented some contribution in this sense. Therefore, as already mentioned in the introduction of this paper, this topic is an opportunity for further investigation.

\subsection{The time dimension and the integration strategies}

The primary goal of adopting a strategy for integrating technologies and products is to reduce risks as well as avoid wastes of the know-how acquired through technology development. According to Iansiti (1998) and Drejer (2002), the loss of the tacit knowledge is a reason for the low efficiency of the innovation process. This loss occurs when someone from the technology development team leaves the organization or stay away from the projects which depend on the technology.

Within this context, the time dimension of the technology-product integration is used to define the integration strategy which is adopted. If there is a large period of time between the technology development and the product development, it can be stated that the integration follows a sequential strategy. On the other hand, if both technology and product development are conducted either at the same period or concurrently, the integration follows a simultaneous strategy. These strategies are also known as strategies of technology synchronization (ELDRED; McGRATH, 1997b), but they are addressed as strategies of technology-product integration in this study.
If a company is unable of separating the time intervals linked to technology and product developments, it can be implied that it does not use deliberately an integration strategy and that technology and product projects are managed without distinction. This fact shows that the time dimension can also be used as a parameter to identify whether companies are applying integration strategies.

The time dimension considers the period in which new technologies are transferred from the technology development to product development (DREJER, 2002; NOBELIUS, 2004). The integration of technologies into products can be made either through a simultaneous or sequential transfer (CUSUMANO; NOBEOKA, 1998). The simultaneous transfer refers to a new product project that uses a new technology whose development is not completed. And, the sequential transfer involves a new product project that uses a new technology whose development is completed.

Magnusson and Johansson (2008) studied the technology-product integration for complex products. They reported that, if the new technology has a low impact on the new product, then the technology and product development are more easily managed as separated processes. Nevertheless, if the time for development is short, both processes can be conducted simultaneously in the beginning of the product development. In contrast, if the new technology has a high impact on the new product, inducting changes in its architecture, both processes requires further interaction and alignment.

\section{Research methodology}

This research aims to contribute to a gap about technology-product integration in SMEs. In the beginning, a literature review was performed to gather information about the state-of-the-art in the field of study. The results were presented in the former section of this paper and underpin the definition of the main construct: the time dimension of strategies for technology-product integration.

The case research method was selected to delineate the development of this work. According to Yin (2003) and Voss, Tsikriktsis and Frohlich (2002), the case research is comprised of four main phases: establishing the research aims and context, choosing cases and preparing instruments and protocol, conducting research and collecting data, and analysing results.

Since the research aim was clear, the next phase was choosing cases and preparing instruments and protocol. At this phase, researchers were looking for SMEs capable of providing data of successful product innovation projects, which were already launched into the market. These selection criteria ensured the analysis of projects which passed throughout the technology and product development processes. A semi-structured questionnaire was created to support data collection. This instrument, which is partly 
presented in the appendix of this paper (Appendix 1), was intended to be used for interviews with managers and was comprised of four parts: data about the company (sector, size and number of employees), data about the product and project, and data about technology-product integration.

Data about products and projects were used to identify project and product characteristics, such as: degree of innovation, innovation trigger, impact of technology on product architecture and success rate in terms of the following metrics: profitability, market share, sales volume and customer satisfaction (GRIFFIN; PAGE, 1996; COOPER; KLEINSCHMIDT, 1995, 2007).

Data about technology-product integration focused on determining the timeline of technology and product development projects. This information supported the identification of the integration strategy (DREJER, 2002). In addition, questions were asked to identify the correct understanding of the technology and product concepts and to verify the presence of specific integration issues. These questions were also a way to confirm whether companies were deliberately using integration strategies (CUSUMANO; NOBEOKA, 1998). If interviewees were incapable of distinguishing technology and product or their timelines, it would be considered that both were jointly developed, without an intentional and integrated approach.

One of the oldest Brazilian technological poles, which was created in 80 's, was the source of companies for this study. A total of 104 SMEs were selected at the beginning. Then, since this study focused on manufacturing companies (tangible products), the sample was reduced to 75 companies. Moreover, only projects with technological innovation and of commercialized products were considered. At the end, 22 projects from 22 SMEs were selected, since they completely fulfilled the requirements and were able to provide the data needed to investigate technology-product integration.

Finally, the data collected were analysed through qualitative techniques (EISENHARDT, 1989). Descriptive charts were used to organize and compare data from all companies and supported a cross-case analysis. Tables and open questions analysis were used for identifying information supplied individually by each company and contributed to insights and theory building.

\section{Description of the companies and projects}

Figure 1 summarizes the companies' industrial sectors. This classification is important because it shows that the electronic and electric industrial sector is a significant part of the sample, followed by the industrial machinery and medical equipment sectors. The FTSE Industry Classification Benchmarking (FTSE..., 2004) was used as reference of industrial sectors.
The number of employees in the companies selected varies from 5 to 85 , which shows that these companies are small, medium or micro enterprises, based on the European Commission framework (2005). The distribution of companies' size is depicted in Figure 2. Although micro enterprises are by definition not include in SMEs, this study decided to include them as part of this group, since they have characteristics that are very similar to small companies. Additionally, the European commission framework also evaluates the annual turnover or the annual balance sheet total to classify enterprises, but companies involved with this study preferred to do not mention their financial values. Then, this criterion was not considered.

Among the 22 projects which were selected, $73 \%$ were classified as "new to the market" and $27 \%$ as "new to the world". Regarding the innovation trigger: $77 \%$ of them were classified as "market-pull" and $23 \%$ as "technology-push" projects.

These projects were also classified in terms of the impact of technology on product development. These data underpins further clarification regarding the projects, since they explain the importance of technology-product integration to product success. The type of impact was

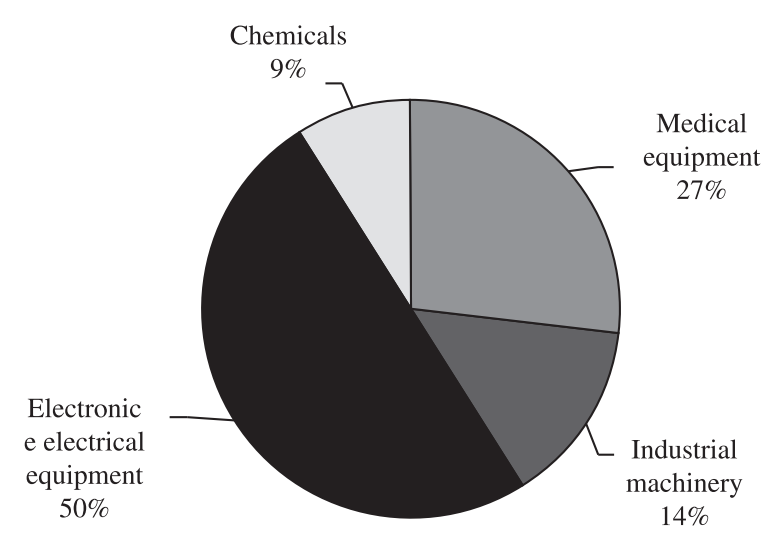

Figure 1. Distribution of the companies among industrial sectors.

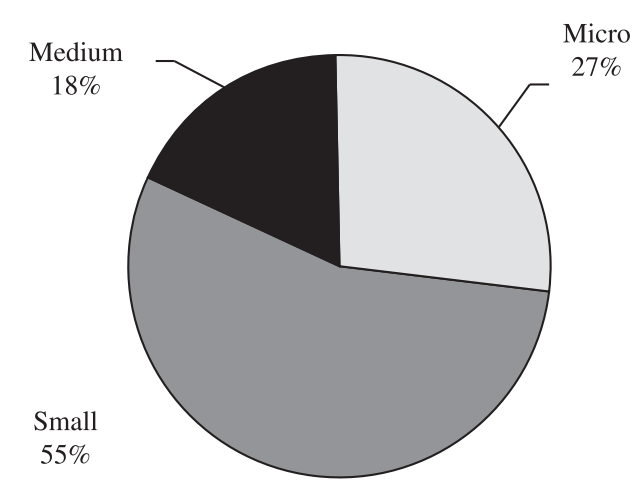

Figure 2. Distribution of companies' size. 
separated into impact on product components, impact on architecture or both. Results are illustrated in Figure 3, in which can be noticed that the majority of these projects depend on technology for succeeding in the product development.

This study also noticed that the same people were often assigned to technology development and product development activities. This fact endorses Schulz et al. (2000), who states that for successful technology-product integration, people from both sides must interact with each other, sharing experiences, knowledge and ideas.

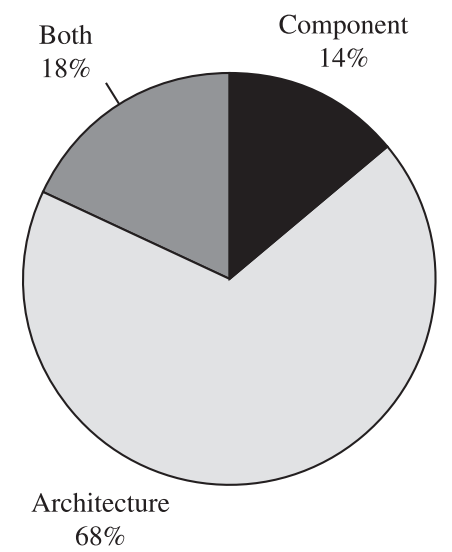

Figure 3. Impact of technology on the product development for the projects selected.

\section{The time dimension of technology-product integration}

Data were collected from the 22 projects to explore whether there was time overlap (simultaneous) between technology and product development or whether these two processes were executed sequentially. Interviewees were asked about the start and finish month/year of the technology development and product development projects which delivered the product innovation under consideration. Results are presented in Table 3.

Nine companies indicated only dates for the technology development. This fact means that these companies did not manage separately technology and product development projects. Then, it can be stated they did not differ technologies and products as proposed by the theory and, consequently, they did not apply integration strategies. This unclear separation between technologies and products has positive and negative effects. The positive one is that there is higher knowledge sharing, since the same team is allocated for the technology and product development. The negative side is that these companies are introducing new technologies without assessing their readiness levels. As a result, the product development has more risks and uncertainties than usually expected, which can either increase time to market and project costs or lead to an unsuccessful product, if the technology fails to meet its performance requirements.

Table 3. Time overlap of the technology and product development for the projects selected.

\begin{tabular}{|c|c|c|c|c|c|c|}
\hline Project (1) & $\begin{array}{c}\text { Technology start } \\
\text { date (2) }\end{array}$ & $\begin{array}{c}\text { Technology finish } \\
\text { date (3) }\end{array}$ & $\begin{array}{c}\text { Product start } \\
\text { date }(4)\end{array}$ & $\begin{array}{c}\text { Product finish } \\
\text { date (5) }\end{array}$ & \begin{tabular}{|c|}
$\begin{array}{c}\text { Time overlap } \\
\text { (6) }\end{array}$ \\
\end{tabular} & $\begin{array}{l}\text { Integration } \\
\text { strategy (7) }\end{array}$ \\
\hline 1 & Mar.-02 & July-05 & - & - & - & - \\
\hline 2 & Dec.-06 & Dec.-07 & - & - & - & - \\
\hline 3 & Mar.-94 & June-05 & June-05 & June-05 & 0 & Sequential \\
\hline 4 & June-00 & Dec. -00 & June-00 & Dec. -00 & 180 & Simultaneous \\
\hline 5 & July-04 & July-06 & Jan.-07 & Feb.-07 & -180 & Sequential \\
\hline 6 & Dec.-05 & June-07 & June-07 & Dec. -08 & 0 & Sequential \\
\hline 7 & June-04 & June-05 & Jan.-05 & Jan.-06 & 150 & simultaneous \\
\hline 8 & June-07 & Oct.-08 & - & - & - & - \\
\hline 9 & June-06 & Jan.-07 & - & - & - & - \\
\hline 10 & Mar.-02 & Dec.-03 & Mar.-04 & June-04 & -90 & Sequential \\
\hline 11 & Mar.-07 & July-07 & - & - & - & - \\
\hline 12 & Oct.-05 & June-06 & June-06 & Jan.-07 & 0 & Sequential \\
\hline 13 & Jan.-02 & June-02 & - & - & - & - \\
\hline 14 & Jan.-06 & June-06 & Jan.-06 & June-06 & 150 & Simultaneous \\
\hline 15 & Sept.-96 & Sept.-98 & - & - & - & - \\
\hline 16 & Oct.-01 & Apr.-02 & - & - & - & - \\
\hline 17 & Mar.-03 & Jan.-04 & Aug.-03 & Jan.-04 & 150 & Simultaneous \\
\hline 18 & Jan.-95 & June-96 & Jan.-99 & Dec. -03 & -930 & Sequential \\
\hline 19 & June-06 & Dec.-06 & June-06 & Dec.-06 & 180 & Simultaneous \\
\hline 20 & May-06 & May-07 & May-07 & May-08 & 0 & Sequential \\
\hline 21 & Sept.-04 & Jan.-06 & Jan.-06 & Feb.-07 & 0 & sequential \\
\hline 22 & Jan.-07 & Dec.-07 & - & - & - & - \\
\hline
\end{tabular}


The remaining thirteen companies provided the start and finish dates of their technology and product projects. These data were used to calculate the time overlap of each innovation project, as indicated in Table 3. The time overlap, which is measured in days, is positive when there is concurrent development of technology and product projects. It is zero when the product development starts immediately after the technology development is finished. And it is negative when there is a time gap between the technology development and product development.

This study adopts that a simultaneous strategy of technology-product integration occurs when the time overlap is positive. In contrast, when it is zero or negative, it is assumed the presence of a sequential strategy. Based on this, five companies were classified as using the simultaneous integration strategy and eight as using the sequential integration strategy.

An analysis of the difference seen between technology and product (question number three and number four of the questionnaire) by the five companies which used simultaneous development indicated that they deal with the technology development as a pre-stage of the product development. Therefore, these companies did not use properly the simultaneous strategy and can be included in the group of companies which did not know the difference between technology and product.

The same action was conducted to investigate the eight companies which were classified as using the sequential strategy, as presented in Table 4.

The results described in Table 4 indicate some contradictory points. Projects 12 and 18 did not present clear separation between product and technology, although these projects have dates that show sequential development. Furthermore, project 3 did not describe the criteria used to define technology and product as well as comments on

Table 4. Analysis of the answers of companies which adopted the sequential strategy.

\begin{tabular}{|c|c|c|c|}
\hline Project & $\begin{array}{c}\text { Is there any } \\
\text { difference between } \\
\text { technology } \\
\text { and product } \\
\text { (question 3)? }\end{array}$ & $\begin{array}{c}\text { Did the } \\
\text { company } \\
\text { indicate the } \\
\text { criteria used } \\
\text { to explain this } \\
\text { difference } \\
\text { (question 4)? }\end{array}$ & $\begin{array}{c}\text { Did the } \\
\text { company } \\
\text { know and use } \\
\text { the sequential } \\
\text { strategy } \\
\text { (question 4 } \\
\text { and 8)? }\end{array}$ \\
\hline 3 & Yes & No & - \\
\hline 5 & Yes & Yes & Yes \\
\hline 6 & Yes & Yes & Yes \\
\hline 10 & Yes & Yes & Yes \\
\hline 12 & No & No & - \\
\hline 18 & No & No & - \\
\hline 20 & Yes & Yes & Yes \\
\hline 21 & Yes & Yes & Yes \\
\hline
\end{tabular}

question 8 , which embraces difficulties faced during project development, suggest that the company though that the technology project was a type of product project. Therefore, projects 3, 12 and 18 were actually not considered as using the sequential integration strategy.

For the last group of projects $(5,6,10,20$ and 21), which this study considered as really applying the sequential integration strategy, further investigation was made through question 8 in order to gather information about integration issues. These companies described some issues primary related to lack of human resources, unskilled employees and partners. Additionally, they indicated problems at the technical development of the product, which may also be an effect of poor technology-product integration.

In the end, these data suggest that the application of integration strategies did not imply fewer problems of integration. In addition, the use of the sequential strategy in SMEs may not achieve the results expected for large companies. Actually, in the SMEs studied, technology-product integration seems to be a way to solve limitations created by scarcity of resources or by project changes, in contrast with large companies, which used the integration to obtain better innovation outcomes.

\section{Conclusions}

A large contribution to the theory of integration strategies in large companies were made by previous studies such as: Iansiti (1998), Drejer (2002) and Schulz et al. (2000). However, in the last years, even with the growing importance of topics related to the fuzzy front-end (VAN DE VRANDE et al., 2009; HUIZINGH, 2011; MÜLLER-SEITZ; REGER, 2010; LICHTENTHALER, 2010; SPITHOVEN et al., 2011; BADAWY, 2011), it seems that less effort has been allocated to explore the integration strategies, both for SMEs and large companies.

The investigation of the integration strategies is a research gap in particular for SMEs. Although they are acknowledged as companies that can assume higher risks and that are responsible for many product innovations, it is unknown how they manage the integration and its impact on their competitiveness. This point turns to be critical when SMEs are participating in innovation ecosystems and networks of an open innovation context.

An analysis of successful product innovation projects of SMEs from a Brazilian technological pole is presented in this paper. The results show that many SMEs often do not recognize differences between technology and product projects. From the 22 companies investigated, 9 did not differentiate these two types of projects, 8 used inadequately the simultaneous and sequential strategies and only 5 used intentionally the sequential strategy as suggested by the theory. In addition, these 5 companies actually applied this strategy for other reasons than reducing technical risks, which is the main reason indicated by previous studies related to this topic. 
Some important conclusions can be drawn by this study. Firstly of all, the integration strategies are also used by SMEs, not only by large companies. The data collected were qualitative, but sufficient to show the differences between the studied companies. Further investigation is required to understand why SMEs apply integration strategies and how they are doing it. Secondly, most of the managers who were interviewed did not know the difference between technologies and products, which is a matter of concern for SMEs.

This study presents a questionnaire that may be reused by other researchers. The approach used on it is based on the time dimension, as introduced by Cusumano and Nobeoka (1998), and proved to be worth for the assessment of integration strategies. It was capable of revealing the situation of the companies, but better criteria is required to analyse the start and finished data in order to separate technology and product development projects. For example, data collected were to such an extent misleading to recognize which companies did adopt the simultaneous strategy. A possible solution would be including a new variable to collect data about assessment of technology readiness. This data could support a better explanation of the integration strategy applied. More sophisticated statistical analysis tools could be used to solve this problem too.

In regard to research limitation, data were collected from a single technological pole and then are restricted to the characteristics of companies within this network. Investigation of other poles would be required to improve findings. Therefore, the findings of this study should not be generalized, but should be seen as a first step towards further progress of technology-product integration for SMEs.

This study suggests for further research a comparison of the integration strategies applied for successful and unsuccessful projects. Another opportunity is the collection of a sample capable of supporting quantitative analysis about the integration strategies in SMEs, which could support more generic conclusions.

\section{References}

AJAMIAN, G. M.; KOEN, P. J. Technology Stage Gate: A Structured Process for Managing High Risk, New Technology Projects. In: BELLIVEAU, P.; GRIFFIN, A.; SOMERMEYER, S. The PDMA Toolbook for new product development. New York: John Wiley \& Sons, 2002. p. 267-295.

BADAWY, M. K. "Is open innovation a field of study or a communication barrier to theory development?": a perspective. Technovation, v. 31, n. 1, p. 65-67, 2011. http:// dx.doi.org/10.1016/j.technovation.2010.09.006

BARCZAK, G.; GRIFFIN, A.; KAHN, K. B. Perspective: trends and drivers of success in NPD practices: results of the 2003 PDMA best practices study. Journal of Product Innovation Management, v. 26, n. 1, p. 3-23, 2009. http:// dx.doi.org/10.1111/j.1540-5885.2009.00331.x
BOS-BROUWERS, H. E. J. Corporate sustainability and innovation in SMEs: evidence of themes and activities in practice. Business Strategy and Environment, v. 19, p. 417-435, 2010.

CLARK, K.; WHEELWRIGHT, S. C. Managing new product and process development: text and cases. New York: Free Press, 1993.

CLAUSING, D.; HOLMES, M. Technology readiness. Research Technology Management, v. 53, n. 4, p. 52-59, 2010.

COOPER, R. G. Managing technology development projects. Research Technology Management, v. 49, n. 6, p. 23-31, 2006.

COOPER, R. G. Perspective: the stage-gate idea-to-launch process - update, what's new, and nexgen systems. Journal of Product Innovation Management, v. 25, n. 3, p. 213-232, 2008. http://dx.doi.org/10.1111/ j.1540-5885.2008.00296.x

COOPER, R. G.; KLEINSCHMIDT, E. J. Benchmarking the firm's critical success factors in new product development. Journal of Product Innovation Management, v. 12, n. 5, p. 374-391, 1995. http://dx.doi. org/10.1016/0737-6782(95)00059-3

COOPER, R. G.; KLEINSCHMIDT, E. J. Winning businesses in product development: the critical success factors. Research Technology Management, v. 50, n. 3, p. 52-66, 2007.

CREVELING, C. M.; SLUTSKY, J. L.; ANTIS, D. Design for six sigma in technology \& product development. New Jersey: Prentice Hall, 2003.

CUSUMANO, M. A.; NOBEOKA, K. Thinking beyond lean: how multi-project management is transforming product development at Toyota and other companies. Free Press, 1998.

DREJER, A. Integrating product and technology development. International Journal of Technology Management, v. 24, n. 2-3, p. 124-142, 2002. http://dx.doi.org/10.1504/ IJTM.2002.003048

EISENHARDT, K. M. Building theories from case study research. The Academy of Management Review, v. 14, n. 4, p. 532-550, 1989.

ELDRED, W.; McGRATH, M. E. Commercializing new technology I. Research Technology Management, v. 40, n. 1, p. 41-47, 1997a.

ELDRED, W.; McGRATH, M. E. Commercializing new technology II. Research Technology Management, v. 40, n. 2, p. 29-33, 1997b.

EUROPEAN COMISSION. The new SME definition: user guide and model declaration. 2005. Available from: $<\mathrm{http}: / /$ ec.europa.eu/enterprise/policies/sme/facts-figures-analysis/ sme-definition/index_en.htm>. Accessed in: Apr. 2012.

FTSE GROUP. FTSE Industry Classification Benchmark. Available from: <http://www.ftse.com/Indices/ 
IndustryClassificationBenchmark/index.jsp >. Accessed in: June 2004.

GRIFFIN, A.; PAGE, A. L. PDMA success measurement project: Recommended measures for product: development success and failure. Journal of Product Innovation Management, v. 13, p. 478-496, 1996. http://dx.doi. org/10.1016/S0737-6782(96)00052-5

HUIZINGH, E. K. R. E. Open innovation: state of the art and future perspectives. Technovation, v. 31, n. 1, p. 2-9, 2011. http://dx.doi.org/10.1016/j.technovation.2010.10.002

IANSITI, M. Technology integration: making critical choices in a dynamic world. Harvard Business School Press, 1998.

JOHANSSON, G. et al. Case studies on the aplication of interface dimensions in industrial innovation process. In: EUROPEAN CONFERENCE ON MANAGEMENT OF TECHNOLOGY - EURO MOT, 2., 2006, Birningham. Proceedings... Birningham, 2006. p. 328-335.

JUGEND, D.; SILVA, S. L. Integration in new product development: case study in a large Brazilian high-technology company. Journal of Technology Management \& Innovation, v. 7, n. 1, p. 52-63, 2012. http://dx.doi. org/10.4067/S0718-27242012000100004

KARLSSON, C.; TAYLOR, M.; TAYLOR, A. Integrating new technology in established organizations: a mapping of integration mechanisms. International Journal of Operations \& Production Management, v. 30, n. 7, p. 672699, 2010. http://dx.doi.org/10.1108/01443571011057290

LAKEMOND, N. et al. Interfaces between technology development, product development and production: critical factors and a conceptual model. International Journal of Technology Intelligence and Planning, v. 3 , n. 4 , p. 317-330, 2007. http://dx.doi.org/10.1504/ IJTIP.2007.016303

LICHTENTHALER, U. Technology exploitation in the context of open innovation: Finding the right 'job' for your technology. Technovation, v. 30, n. 7-8, p. 429-435, 2010. http://dx.doi.org/10.1016/j.technovation.2010.04.001

MAGNUSSON, T.; JOHANSSON, G. Managing internal technology transfer in complex product development. European Journal of Innovation Management, v. 11, n. 3, p. 349-365, 2008. http://dx.doi. org/10.1108/14601060810889008

MANKINS, J. C. Technology readiness levels. 1995. White paper. Available from: <http://www.hq.nasa.gov/office/ codeq/trl/trl.pdf>. Accessed in: June 2011.

MÜLLER-SEITZ, G.; REGER, G. Networking beyond the software code? an explorative examination of the development of an open source car project. Technovation, v. 30, n. 11-12, p. 627-634, 2010. http://dx.doi.org/10.1016/j. technovation.2010.07.006
NOBELIUS, D. Linking product development to applied research: transfer experiences from automotive company. Technovation, v. 24, n. 4, p. 321-334, 2004. http://dx.doi. org/10.1016/S0166-4972(02)00073-1

OLIVEIRA, M. G. et al. A starting point for addressing product innovativeness in the Fuzzy Front-End. International Journal of Technology Intelligence and Planning, v. 7 , n. 4, p. 309-326, 2011. http://dx.doi.org/10.1504/ IJTIP.2011.045092

PHAAL, R.; FARRUKH, C. J. P.; PROBERT, D. R. A framework for supporting the management of technological knowledge. International Journal of Technology Management, v. 27, n. 1, p. 1-15, 2004. http://dx.doi. org/10.1504/IJTM.2004.003878

ROPER, S. Product innovation and small business growth: A comparison of the strategies of German, UK and Irish companies. Small Business Economics, v. 9, n. 6, p. 523-537, 1997. http://dx.doi. org/10.1023/A:1007963604397

SCHULZ, A. P. et al. Development and integration of winning technologies as key to competitive advantage. Systems Engineering, v. 3, n. 4, p. 180-211, 2000. http://dx.doi. org/10.1002/1520-6858(2000)3:4<180::AID-SYS2>3.0. $\mathrm{CO} ; 2-\mathrm{H}$

SPITHOVEN, A.; CLARYSSE, B.; KNOCKAERT, M. Building absorptive capacity to organise inbound open innovation in traditional industries. Technovation, v. 31, n. 1, p. 10-21, 2011. http://dx.doi.org/10.1016/j. technovation.2010.10.003

STAM, E.; WENNBERG, K. The roles of R\&D in new firm growth. Small Business Economics, v. 33, n. 1, p. 77-89, 2009. http://dx.doi.org/10.1007/s11187-009-9183-9

STOCK, G. N.; TATIKONDA, M. V. External technology integration in product and process development. International Journal of Operations \& Production Management, v. 24, n. 7, p. 642-665, 2004. http://dx.doi. org/10.1108/01443570410541975

VAN DE VRANDE, V. et al. Open innovation in SMEs: trends, motives and management challenges. Technovation, v. 29, n. 6-7, p. 423-437, 2009. http://dx.doi.org/10.1016/j. technovation.2008.10.001

VOSS, C.; TSIKRIKTSIS, N.; FROHLICH, M. Case research in operations management. International Journal of Operations \& Production Management, v. 22, n. 2, p. 195-219, 2002. http://dx.doi. org/10.1108/01443570210414329

YIN, R. K. Case Study Research: design and methods. Thousand Oaks: Sage Publications, 2003. 
Appendix 1. Core questions used in the instrument of data collection.

Section B - Data about project and product

1. The levels of product innovation can be characterized as:

( ) New to the company ( ) New to the market ( ) New to the world

\section{Section C - Data about project results}

2. On a scale of 1 to 5 , where scale 1 is too low expectations and scale 5 is too high expectations, how would you rate product success in relation to:

\begin{tabular}{|c|c|c|c|c|c|}
\hline Product success in terms of & Too low expectations & Low expectations & As expected & High expectations & $\begin{array}{c}\text { Too high } \\
\text { expectations }\end{array}$ \\
\hline Profitability & 1 & 2 & 3 & 4 & 5 \\
\hline Market share & 1 & 2 & 3 & 4 & 5 \\
\hline Sales volume & 1 & 2 & 3 & 4 & 5 \\
\hline Client satisfaction & 1 & 2 & 3 & 4 & 5 \\
\hline
\end{tabular}

\section{Section D - Data about integration technology and product development}

3. Is there any difference between technology and the product?

( ) Yes ( ) No

4. If the last answer is "Yes", please indicate the criteria used to explain such difference.

5. Please indicate which source of original idea generated the main technology of the product.

( ) contact with a specific client

( ) retailer

( ) technical assistance

( ) comparative analysis with market products

( ) marketing survey

( ) another product

( ) literature

( ) patent indexes

( ) Doctorate thesis and mater dissertations

( ) thes:

6. Please indicate the time spent during the main technology development

$($,

$($,

month, year

beginning

"total lead time" month, year

final

7. Please indicate the time spent during the product development

$($,

month, year

beginning

"total lead time"

month, year

$$
(,)
$$

final

8. What difficulties did you face from the beginning of the project development to the product launching? 